\title{
KEDAULATAN HUKUM
}

\author{
INDRA SYAHPUTRA \\ syahputra.indra0606@gmail.com \\ 2010003600344 \\ UNIVERSITAS EKA SAKTI
}

\section{A. PENDAhuluan}

Kedaulatan merupakan terjemahan dari kata sovereignty (Bahasa Inggris) atau souverinete (Bahasa Perancis) atau sovranus (Bahasa Italia). Jean Bodin menganggap kedaulatan sebagai atribut negara, sebagai ciri khusus dari negara. Menurutnya, kedaulatan merupakan hal pokok dari kesatuan politik yang disebut negara. Menurutnya, kedaulatan merupakan hal pokok dari kesatuan politik yang disebut negara. Kedaulatan mengandung satu-satunya kekuasaan yang: (1) Asli, yaitu tidak diturunkan dari suatu kekuasaan lain; (2) Tertinggi, yaitu tidak ada kekuasaan lain yang lebih tinggi yang dapat membatasi kekuasaannya; (3) Bersifat abadi atau kekal; (4) Tidak dapat dibagi-bagi karena hanya ada satu kekuasaan tertinggi; (5) Tidak dapat dipindahkan atau diserahkan kepada badan lain.Jadi dari pernyataan tersebut dapat dikatakan bahwa kedaulatan berarti kekuasaan tertinggi pada suatu negara atau kekuasaan yang tidak terletak di bawah kekuasaan negara lain. Namun kedaulatan suatu negara tidak bersifat mutlak atau absolut, tetapi pada batas-batas tertentu harus menghormati kedaulatan negara lain, yang diatur melalui hukum internasional. Dalam konteks hukum internasional, negara yang berdaulat pada hakikatnya harus tunduk dan menghormati hokum 
internasional. Kedaulatan negara merupakan karakter negara yang secara politik merdeka, baik secara de jure maupun secara de facto.

Kedaulatan itu pada dasarnya mengandung dua aspek, yang pertama aspek internal yaitu berupa kekuasaan tertinggi untuk mengatur segala sesuatu yang ada atau yang terjadi di dalam batas-batas wilayahnya, kedua adalah aspek eksternal yaitu kekuasaan tertinggi untuk mengadakan hubungan dengan anggota masyarakat internasional maupun mengatur segala sesuatu yang berada atau yang terjadi di luar wilayah negara itu sepanjang masih ada kaitannya dengan kepentingan negara itu. Menurut Mochtar Kusumaatmadja, kedaulatan merupakan suatu sifat atau ciri hakiki dari suatu negara, dimana negara tersebut berdaulat dengan batas-batasnya, yaitu ruang berlakunya kekuasaan tertinggi ini dibatasi oleh batas-batas wilayah negara itu, diluar wilayahnya negara tersebut tidak lagi memiliki kekuasaan demikian. Istilah kedaulatan sendiri seringkali dijumpai atau ditemukan dalam berbagai macam pengertian dan masing-masing memiliki perbedaan yang prinsipil. Misalnya pengertian kedaulatan apabila dimaknai dalam perspektif hukum Internasional yang sering dipandang dalam hubungan ekstern atau hubungan antar negara, sedangkan dalam perspektif hukum tata negara dipandang dalam hubungan intern yaitu hubungan negara ke dalam. Kedaulatan dipandang juga sebagai konsep mengenai kekuasan tertinggi dalam penyelenggaraan negara.

Berkenaan dengan hal tersebut, kedaulatan tidak dipandang sebagai sesuatu yang bulat dan utuh, melainkan dalam batas-batas tertentu tunduk 
pada pembatasan-pembatasan yang berupa hukum internasional. Dengan demikian suatu negara yang berdaulat tetap saja tunduk pada hukum internasional serta tidak boleh melanggar atau merugikan kedaulatan negara lain. Negara Kesatuan Republik Indonesia sebagai negara kepulauan yang berciri nusantara mempunyai kedaulatan atas wilayahnya untuk dikelola dan dimanfaatkan sebesar-besarnya bagi kesejahteraan dan kemakmuran rakyat Indonesia sebagaimana yang telah diamanatkan dalam Undang-Undang Dasar Negara Republik Indonesia Tahun 1945.

\section{B. PEMBAHASAN}

\section{Pengertian Kedaulatan.}

Kedaulatan merupakan kekuasaan tertinggi dalam suatu negara. Kedaulatan dimiliki olehbangsa sejak merdeka dari penjajahan bangsa lain. Kedaulatan memiliki sifat permanen, asli, dan tidak tebatas.Kedaulatan Hukum Merupakan Modal awal dalam pembentukan sebuah negara dimana semua elemen masyarakat disatukan dalam payung pemerintahan yang memiliki kedaulatan dalam hukum. Oleh sebab itu kedaulatan membutuhkan hukum yang kuat dalam rangka menjaga kedaulatan tersebut.

Didalam kedaulatan hukum kekuasaan tertinggi dalam suatu negara adalah hukum. Raja atau penguasa serta rakyat semuanya tunduk terhadap hukum. Semua tindakan yang dilakukan oleh raja, kepala negara atau rakyat harus sesuai dengan hokum yang berlaku. Sumber dari hukum itu 
sendiri adalah dari kesadaran masyarakat yang memiliki rasa membuat hukum yang baik. Dengan adanya kesadaran akan hukum, maka masyarakat mengeluarkan perasaan sehingga mampu membedakan adanya norma - norma yang terlepas dari kehendak kita.

\section{Definisi Kedaulatan Hukum}

Pengertian Kedaulatan hukum adalah apabila segala sesuatu yang berkenaan dengan hubungan antara penguasa dan rakyat mengacu pada aturan yang telah disepakati bersama tidak hanya pada keinginan salah satu pihak khususnya penguasa. Kedaulatan hukum dapat juga dikatakan dengan negara hukum. kedaulatan yang berasal dari hukum yang berlaku di suatu negara. Dimana Hukum merupakan pernyataan yang timbul dari kesadaran manusia, dan merupakan sumber kedaulatan. Setiap Negara harus mematuhi tata tertib hukum, sebab Hukum merupakan kekuasaan yang derajatnya lebih tinggi. Negara hanya sebagai organisasi sosial yang tunduk kepada hukum. Kekuasaan negara harus berpijak dan berlandaskan hukum. Hukum harus dipandang sebagai sumber dari segala sumber kekuasaan dalam negara maksudnya kekuasaan yang dimiliki oleh pemerintah itu didapat atau diatur oleh hukum yang berlaku di negara itu, sehingga kekuasaanitu sah berdasarkan hukum yang berlaku. 


\section{Teori Kedaulatan Hukum}

Teori kedaulatan hukum menunjukkan bahwa kekuasaan yang tertinggi bukan terletak di tangan raja dan bukan juga berada di tangan negara, melainkan berada ditangan hukum. Teori ini menyatakan bahwa hukum merupakan pernyataan penilaian yang muncul atau bersumber pada kesadaran hukum manusia itu sendiri. Kedaulatan hukum merupakan sumber kedaulatan dimana kesadaran hukum seseorang akan membuatnya mampu membedakan mana sesuatu yang adil dan mana sesuatu yang tidak adil. Teori ini juga dapat dikaitkan dengan prinsip Rule of Law yang dikembangkan oleh seorang A.V. Dicey. Prinsip yang kemudian berkembang di Amerika Serikat juga menjadi jargon The Rule of Law and Not a Man yakni prinsip yang menganggap bukan orang yang menjadi pemimpin tetapi hukum sebagai pemimpin itu sendiri. Berdasarkan pemikiran teori ini, kekuasaan pemerintah berasal dari hukum yang berlaku. Hukumlah yang membimbing kekuasaan pemerintahan. Etika normatif negara yang menjadikan hukum sebagai "panglima" mewajibkan penegakan hukum dan penyelenggara negara dibatasi oleh hukum.

Perintis Teori Kedaulatan Hukum adalah seorang ahli hukum terkemuka dari Universitas Leiden, Belanda , Hugo Krabbe (1857 - 1936). Dia belajar hukum dan ilmu Negara di Leiden dan menyelesaikan studi tahun 1883 dengan tesis "De burgerlijke staatsdienst in Nederland"(Pelayanan Negara Borjuis di Belanda). Beberapa tahun kemudian bekerja di Sekretariat Provinsi Gelderland dan Noord 
Holland. Tahun 1894 Krabbe ditunjuk sebagai professor di Groningen, dengan pidato pengukuhan "de werkkring van de staat"(Jabatan-jabatan Negara). Tahun 1897 membuat suatu laporan prasaran berjudul Hubungan hukum antara Negara dan pejabat-pejabatnya harus diatur oleh hukum. Dia kembali ke Universitas Leiden menduduki jabatan bergengsi prof.Oppenheim sebagai professor hukum konstitusi/tata Negara tahun 1908 dengan pidato "De idee der rechtspersoonlijkheid in de Staatsleer" (Ide subyek hukum dalam ajaran Negara). Disini dia lebih mendalam menyoroti hubungan antara hukum dan Negara. Sebelumnya di Groningen Krabbe telah mengemukakan ide kedaulatan hukum dalam buku "Die Lehre der Rechtssouveränität; Beitrag zur Staatslehre" (Ajaran Kedaulatan hukum, Groningen, 1906). Untuk lebih menjabarkan buku ini ditulis lagi buku "De modern staatsidee" (Ide Negara modern), den Haag 1915 lalu "het Rechtgezag" (Kewenangan hukum, Den Haag 1917), "De innerlijke waarheid der wet ("Kebenaran internal dari undang-undang" di "s-Gravenhage, 1924). Murid Krabbe yang terkenal adalah R.Kranenburg yang menulis "Algemene Staatslehre" (Ilmu Negara Umum).

Teori Kedaulatan hukum dari Krabbe berusaha memecahkan masalah teori kedaulatan Negara juga teori kedaulatan rakyat yang sudah ada sebelumnya. Jean Bodin (1576) adalah yang pertama kali merumuskan bahwa kedaulatan adalah sifat utama dari Negara. Negara berdaulat atas warganya dan Negara tidak dapat dihambat oleh hukum. 
Orang yang berkuasa adalah sumber dari hukum dan ia tidak terikat pada hukum. Ia hanya tunduk pada hukum illahi dan hukum kodrat dan hanya bertanggung jawab kepada Tuhan saja. Sifat Kedaulatan menurut Jean Bodin (1530 - 1596) kedaulatan mempunyai empat sifat pokok yaitu:

a. Permanen, artinya kedaulatan yang tetap ada selama negara berdiri.

b. Asli, artinya kedaulatan itu tidak berasal dari kekuasaan lain yang lebih tinggi.

c. Bulat/tidak dapat dibagi-bagi, artinya kedaulatan itu hanya satusatunya kekuasaantertinggi.

d. Tidak terbatas, artinya kedaulatan tidak ada yang membatasi, sebab apabila terbatas,maka sifat tertinggi akan lenyap

Bahkan hukum itu tidak tergantung pada kehendak manusia, yaitu hukum adalah sesuatu dengan kekuatan memerintah yang terdapat dalam perasaan hukum manusia, yang sering memaksa manusia bertindak juga bertentangan dengan kehendaknya sendiri atau bertentangan dengan suatu kecenderungan tertentu padanya. Bukan hanya manusia di bawah perintah hukum, negara pun di bawah perintah hukum. Hukum berdaulat, yaitu diatas segala sesuatu, termasuk negara. Kelemahan teori Krabbe adalah teori tersebut tidak dapat diterima, karena kaidah yang berasal dari perasaan hukum seseorang hanya berlaku baginya saja. Jadi apabila tiap orang mempunyai anggapan sendiri tentang hukum, maka hukum yang berdasarkan anggapan sendiri itu jumlah dan macamnya tidak terkira banyaknya. 
Sedangkan tata tertib masyarakat menghendaki adanya hukum yang sama bagi semua orang; jika tidak demikian, maka masyarakat menjadi kacau (anarki). Setelah mengetahui kekurangan ini, maka Krabbe mengubah teori tersebut dan membuat batasan yang baru yang berbunyi: "Hukum berasal dari perasaan hukum yang ada pada bagian besar dari anggota suatu masyarakat." (Menurut Krabbe, maka negara seharusnya negara hukum (rechtsstaat)). Tiap tindakan negara harus dapat dipertanggung jawabkan pada hukum.

Konsep negara hukum itu menjadi cita-cita kenegaraan pada zaman modern. Jadi perbedaan antara kedaulatan negara dengan kedaulatan hukum adalah: penganut teori kedaulatan negara, mengatakan bahwa negara menciptakan hukum, sedangkan penganut teori kedaulatan hukum, justru sebaliknya, hukumlah yang menciptakan negara. Negara yang menjalankan pemerintahannya berdasarkan hukum dinamakan negara hukum atau nomokrasi (nomoi = hukum; kratein $=$ menguasai, memerintah). Dasar-dasar (asas-asas) negara hukum itu sendiri adalah: asas legaliteit, asas perlindungan kebebasan dan hak pokok manusia atas semua orang yang ada di wilayah negara, dalam hal kebebasan dan hak ini sesuai dengan kesejahteraan umum. Yang dimaksud dengan asas legaliteit adalah bahwa semua tindakan alat-alat negara (staatsorganen) harus didasarkan atas dan dibatasi oleh peraturan perundang-undangan. 
Yang mempunyai kekuasaan tertinggi dalam negara ialah UndangUndang Dasar yang terdiri atas peraturan-peraturan hukum dan asas-asas hukum. Negara hukum modern (moderne rechsstaat) sendiri bertugas melindungi kebebasan dan hak pokok tiap orang yang berada di wilayahnya. Perlindungan tersebut tidak hanya bersifat pasif tetapi juga harus bersifat aktif dalam rangka menyelenggarakan kesejahteraan bagi rakyat.

Teori kedaulatan rakyat yang dipelopori John Locke dan dikembangkan oleh J.J.Rousseauyang meletakkan kedaulatan kepada seluruh rakyat. Tapi teori tidak cukup jelas karena ada dua unsur yang tidak bisa dikombinasi. Telah diuraikan dimuka konsep kedaulatan Bodin memandang kekuasaan tertinggi berada di tangan Raja sebagai wakil dari Negara. Setelah Revolusi Prancis kekuasaan itu tidak lagi pada Raja tapi pada Raja di Parlemen. Tujuan revolusi tentu saja bukan hanya sekedar memindahkan kekuasaan absolute itu ketangan yang lain. Tujuannya kata Locke agar supaya kekuasaan itu tidak digunakan sewenang-wenang oleh Raja maupun oleh kelompok orang tertentu. Apakah kedaulatan berada pada rakyat (people). Rakyat adalah kumpulan warga Negara yang tidak berbentuk dan karenanya tidak memiliki makna politik dan hukum. Mencari-cari letak kedaulatan pada organ Negara adalah sia sia. 


\section{Kelebihan dan kelemahan Teori Kedaulatan Hukum.}

\section{Kelebihan Teori Kedaulatan Hukum :}

- Hukum memegang peranan penting dalam negara. Hukum lebih tinggi dari negara yang berdaulat. Artinya, Dalam asal mula negara berdasarkan teori kedaulatan hukum mempunyai peranan yang penting dalam kehidupan masyarakatnya,hukum harus tetap ditegakkan, Bagaimana hukum dibuat begitulah seharusnya penyelanggaraan negara.

- Teori kedaultan hukum mengakibatkan kondisi pemerintahan yang serba seragam dan tingkat kedisiplinan di negara sangat tinggi.Kondisi ini menciptakan keteraturan dalam segala sektor dan membuat negara berkembang secara cepat dan teratur.

- Melindungi kebebasan dan hak pokok tiap orang yang berada di wilayahnya. Perlindungan tersebut tidak hanya bersifat pasif tetapi juga harus bersifat aktif dalam rangka menyelenggarakan kesejahteraan bagi rakyat.

- Sanksi terhadap pelanggaran peraturan tersebut adalah tegas dan bersifat memaksa

\section{Kelemahan Teori Kedaulatan Hukum :}

- Pemerintahan yang cenderung pro mayoritas dan hukum menjadi represif, khususnya bagi kaum minoritas. Teori ini cenderung menyeragamkan semua pola pikir masyarakatnya pada suatu norma tertentu, yaitu normanorma masyarakatnya mayoritas negara itu. Penyeragaman ini mematikan 
daya kreativitas suatu negara dan menyebabkan gap yang signifikan antara kaum minoritas dan mayoritas.

- Timbul campur tangan politik. Hal yang lumrah untuk dilontarkan karena kasus-kasus besar dan berdimensi struktural setidaknya melibatkan partai politik penguasa negara.

- Rendahnya integritas moral,kredibilitas, profesionalitas dan kesadaran hukum aparat penegak hukum dalam menegakan hukum. Karena Hukum tidak lepas dari para penegak hukum.

\section{PENUTUP}

Kedaulatan hukum adalah apabila segala sesuatu yang berkenaan dengan hubungan antara penguasa dan rakyat mengacu pada aturan yang telah disepakati bersama tidak hanya pada keinginan salah satu pihak khususnya penguasa. Kedaulatan hukum dapat juga dikatakan dengan negara hukum. kedaulatan yang berasal dari hukum yang berlaku di suatu negara. Teori kedaulatan hukum menunjukkan bahwa kekuasaan yang tertinggi bukan terletak di tangan raja dan bukan juga berada di tangan negara, melainkan berada ditangan hukum. Teori ini menyatakan bahwa hukum merupakan pernyataan penilaian yang muncul atau bersumber pada kesadaran hukum manusia itu sendiri. Kedaulatan hukum merupakan sumber kedaulatan dimana kesadaran hukum seseorang akan membuatnya mampu membedakan mana sesuatu yang adil dan mana sesuatu yang tidak adil. 
Indonesia menganut teori kedaulatan rakyat dan kedaulatan hukum. Kedaulatan yang diterapkan di Indonesia adalah kedaulatan yang berdasarkan Pancasila dengan semangat Bhinneka Tunggal Ika. Kedaulatan merupakan masalah yang sangat pokok dalam kehidupan berbangsa dan bernegara. Karena adanya pengakuan kedaulatan oleh Negara-negara lain, berarti eksistensi suatu negara diakui. Maka dengan adanya landasan kedaulatan tersebut, suatu negara dapat menjalankan berbagai macam hubungan dan jalinan kerjasama dengan negara-negara maupun lembaga-lembaga internasional untuk lebih meningkatkan kepentingan nasional dan kemajuan bangsanya. Kedaulatan hukum merupakan sumber kedaulatan dimana kesadaran hukum seseorang akan membuatnya mampu membedakan mana sesuatu yang adil dan mana sesuatu yang tidak adil. Berdasarkan pemikiran teori ini, kekuasaan pemerintah berasal dari hukum yang berlaku. Hukumlah yang membimbing kekuasaan pemerintahan. Etika normatif negara yang menjadikan hukum sebagai "panglima" mewajibkan penegakan hukum dan penyelenggara negara dibatasi oleh hukum. 


\section{DAFTAR PUSTAKA}

Darmini Roza dan Laurensius Arliman S, Peran Pemerintah Daerah Di Dalam Melindungi Hak Anak Di Indonesia, Masalah-Masalah Hukum, Volume 47, Nomor 1, 2018.

Laurensius Arliman S, Komnas HAM dan Perlindungan Anak Pelaku Tindak Pidana, Deepublish, Yogyakarta, 2015.

Laurensius Arliman S, Penguatan Perlindungan Anak Dari Tindakan Human Trafficking Di Daerah Perbatasan Indonesia, Jurnal Selat, Volume 4, Nomor 1, 2016.

Laurensius Arliman S, Problematika Dan Solusi Pemenuhan Perlindungan Hak Anak Sebagai Tersangka Tindak Pidana Di Satlantas Polresta Pariaman, Justicia Islamica, Volume 13, Nomor 2, 2016.

Laurensius Arliman S, Pelaksanaan Perlindungan Anak Yang Tereksploitasi Secara Ekonomi Oleh Pemerintah Kota Padang, Veritas et Justitia, Volume 2, Nomor 1, 2016.

Laurensius Arliman S, Kedudukan Ketetapan MPR Dalam Hierarki Peraturan Perundang-Undangan Di Indonesia, Lex Jurnalica, Volume 13, Nomor 3, 2016.

Laurensius Arliman S, Komnas Perempuan Sebagai State Auxialiary Bodies Dalam Penegakan Ham Perempuan Indonesia, Justicia Islamica, Volume 14, Nomor 2, 2017. 
Laurensius Arliman S, Peranan Pers Untuk Mewujudkan Perlindungan Anak Berkelanjutan Di Indonesia, Jurnal Ilmu Hukum Tambun Bungai, Volume 2, Nomor 2, 2017.

Laurensius Arliman S, Mewujudkan Penegakan Hukum Yang Baik Untuk Mewujudkan Indonesia Sebagai Negara Hukum, Jurnal Hukum Doctrinal, Volume 2, Nomor 2, 2017.

Laurensius Arliman S, Participation Non-Governmental Organization In Protecting Child Rights In The Area Of Social Conflict, The 1st Ushuluddin and Islamic Thought International Conference (Usicon), Volume 1, 2017.

Laurensius Arliman S, Partisipasi Masyarakat Dalam Pembentukan Perundang-Undangan Untuk Mewujudkan Negara Kesejahteraan Indonesia, Jurnal Politik Pemerintahan Dharma Praja, Volume 10, Nomor 1, 2017, https://doi.org/10.33701/jppdp.v10i1.379.

Laurensius Arliman S, Peran Komisi Perlindungan Anak Indonesia Untuk Mewujudkan Perlindungan Anak, Jurnal Respublica Volume 17, Nomor 2, 2018.

Laurensius Arliman S, Menjerat Pelaku Penyuruh Pengrusakan Barang Milik Orang Lain Dengan Mempertimbangkan Asas Fungsi Sosial, Jurnal Gagasan Hukum, Volume 1, Nomor 1, 2019.

Laurensius Arliman S, Ilmu Perundang-Undangan Yang Baik Untuk Negara Indonesia, Deepublish, Yogyakarta, 2019. 
Laurensius Arliman S, Isdal Veri, Gustiwarni, Elfitrayenti, Ade Sakurawati, Yasri, Pengaruh Karakteristik Individu, Perlindungan Hak Perempuan Terhadap Kualitas Pelayanan Komnas Perempuan Dengan Kompetensi Sumber Daya Manusia Sebagai Variabel Mediasi, Jurnal Menara Ekonomi: Penelitian dan Kajian Ilmiah Bidang Ekonomi, Volume 6, Nomor 2, 2020.

Laurensius Arliman S, Pendidikan Kewarganegaraan, Deepublish, Yogyakarta, 2020.

Laurensius Arliman S, Makna Keuangan Negara Dalam Pasal Pasal 23 E Undang-Undang Dasar 1945, Jurnal Lex Librum, Volume 6, Nomor 2 Juni 2020, http://dx.doi.org/10.46839/1ljih.v6i2.151.

Laurensius Arliman S, Kedudukan Lembaga Negara Independen Di Indonesia Untuk Mencapai Tujuan Negara Hukum, Kertha Semaya Journal Ilmu Hukum, Volume 8, Nomor 7, 2020.

Laurensius Arliman S, Pelaksanaan Assesment Oleh Polres Kepulauan Mentawai Sebagai Bentuk Pelaksanaan Rehabilitasi Bagi Pecandu Dan Korban Penyalahgunaan Narkotika, Jurnal Muhakkamah, Volume 5, Nomor 1, 2020.

Laurensius Arliman S, Aswandi Aswandi, Firgi Nurdiansyah, Laxmy Defilah, Nova Sari Yudistia, Ni Putu Eka, Viona Putri, Zakia Zakia, Ernita Arief, Prinsip, Mekanisme Dan Bentuk Pelayanan Informasi Kepada Publik Oleh Direktorat Jenderal Pajak, Volume 17, No Nomor, 2020. 
Larensius Arliman S, Koordinasi PT. Pegadaian (Persero) Dengan Direktorat Reserse Narkoba Polda Sumbar Dalam Penimbangan Barang Bukti Penyalahgunaan Narkotika, UIR Law Review, Volume 4, Nomor 2, 2020, https://doi.org/10.25299/uirlrev.2020.vol4(1).3779.

Laurensius Arliman S, Tantangan Pendidikan Kewarganegaraan Pada Revolusi 4.0, Ensiklopedia Sosial Review, Volume 2, Nomor 3, 2020.

Muhammad Afif dan Laurensius Arliman S, Protection Of Children's Rights Of The Islamic And Constitutional Law Perspective Of The Republic Of Indonesia, Proceeding: Internasional Conference On Humanity, Law And Sharia (Ichlash), Volume 1, Nomor 2, 2020.

Otong Rosadi danLaurensius Arliman S, Urgensi Pengaturan Badan Pembinaan Idelogi Pancasila Berdasarkan Undang-Undang Sebagai State Auxiliary Bodies yang Merawat Pancasila dalam Perspektif Hak Asasi Manusia, Prosiding Konferensi Nasional Hak Asasi Manusia, Kebudayaan dan Tujuan Pembangunan Berkelanjutan Indonesia pada Masa Pandemi Covid-19: Tantangan untuk Keilmuan Hukum dan Sosial Volume 1, Universitas Pancasila, Jakarta, 2020. 